\title{
Self-regulation from Educational Psychology to L2 Pedagogy: an Alternative to Language Learning Strategies
}

\author{
Maryam Banisaeid (Corresponding author) \\ School of International Studies, Zhejiang University \\ Zijingang Campus, Zhejiang University, Hangzhou, PR China, 310058 \\ Tel: 15382320064 E-mail: banymary@yahoo.com \\ Jianbin Huang \\ School of International Studies, Zhejiang University \\ Zijingang Campus, Zhejiang University, Hangzhou, PR China, 310058 \\ Tel: 13185030966 E-mail: jianbinhuang32@126.com
}

Received: 24-10-2013

Accepted: 05-12-2013

Published: 01-01-2014

doi:10.7575/aiac.ijalel.v.3n.1p.240

URL: http://dx.doi.org/10.7575/aiac.ijalel.v.3n.1p.240

\begin{abstract}
Language learning strategy was the focus of many studies during the last two decades. Because of definitional fuzziness and unreliable instrument, the concept of language learning strategy was replaced by self-regulation in educational psychology. Subsequently, this shift affected L2 research. The notion of self-regulation is used in some L2 studies today (Tseng, Dörnyei \& Schmitt, 2006; Rose, 2011b, Banisaeid, 2013a, 2013b). Self-regulation is more process-oriented while language learning strategy is more product-oriented. Although it only encompasses the metacognitive strategy, the general domain of it is meaningfully wider than the strategic framework. It covers some aspects in the learning process as motivation, goals and self-efficacy.
\end{abstract}

Keywords: self-regulation, language learning strategy, L2 studies, educational psychology

\section{Introduction}

After more than two decades research on language learning strategies, it is believed that strategic framework should be replaced by self-regulated learning (Tseng, Dörnyei \& Schmitt, 2006; Rose, 2011a, Dörnyei, 2005).

Although the theoretical inconsistencies surrounding the learning strategy literature in general had been known since the early days, it was not at all unreasonable that the L2 field showed remarkable tolerance of these shortcomings. (Dörnyei, 2005, p. 169)

He also concludes that learning strategy renders a shift not only in educational psychology in favor of the selfregulation, but also in $\mathrm{L} 2$ research.

\section{Language learning strategies}

The first attempt that led to some very careful defining of specific learning strategies came from works on poor and good learners and individual variations by Rubin and Stern in the mid 1970s (Brown, 2000). This beginning point was then followed by many other scholars who tried to shaped different classifications of language learning strategies (O’malley \& Chamot, 1989; Oxford, 1990, Nation, 1990; Dornyei, 1995)

Ellis (1994) emphasizes on the mediating role of strategy between learners and situational factors and learning outcomes. He defined learning strategy as "the particular approaches or techniques that learners employ to try to learn an L2" (1997, P. 76-77).

Although there are many definitions for language learning strategies (Rubin, 1975; Stern; 1975, 1986, 1992; Naiman, Fröhlich. Stern \& Todesco, 1978; Tarone ,1981; Chamot ,1987; Weinstein \& Mayer ,1986; Wenden ,1987; Schmeck ,1988; O×Malley \& Chamot ,1990; Oxford ,1990; Ellis ,1994; Ridley ,1997; Cohen ,1998; Purpura ,1999; Goh ,1998, 2002), Ellis (1994) lists some problems underlying these definition:

1. It is not clear that learning strategy is something mental or behavioral.

2. There is considerable uncertainty on the precise nature of the behavior.

3. It is not clear that learning strategies are to be seen as conscious and intentional or subconscious.

4. Whether learning strategies are seen as having a direct or indirect effect on interlanguage progress.

5. There are differences in opinions about what motivated the use of learning strategies. 
Rose (2011a, 2011b) declares that language learning strategy classification system is criticized regarding definitional fuzziness and invalid and unreliable research instrument.

Dörnyei (2005) notes that based on the strategy theory, the quality of the employed strategies are important in the strategy use, while in Strategy Inventory for Language Learning, it is the quantity that matters:

"Thus, the scales in the SILL are not cumulative and computing mean scale scores is psychometrically not justifiable. A high score on the SILL is achieved by a learner using as many different strategies as possible and therefore it is largely the quantity that matters. This is in contradiction with strategy theory, which has indicated clearly that in strategy use it is not necessarily the quantity but the quality of the employed strategies that is important....all this means that although the SILL may be a useful instrument for raising student awareness of L2 learning strategies and for initiating class discussions, its use for research purposes is questionable (p.182-183)"

These problems in the framework of language learning strategies make some scholars to think about replacing it with self-regulation (Dornyei, 2005; Rose, 2011a; Tseng et. al., 2006).

Dörnyei (2005) expresses the differences between self-regulation and language learning strategy. Self-regulation is process oriented while language learning strategy is product oriented. The former is a dynamic concept that has a broader perspective. He believes that self-regulation is a more general term for learning strategy use. The term learning strategy was replaced by the more versatile concept of self-regulation (Dörnyei, 2005, p. 170)

\section{A brief history of self-regulation}

Self-regulated learning is a newly derived topic from educational psychology to language learning field. It was first introduced in 1978 by Vygotsky's works on children learning and cognitive development (Duckworth, Rodie Akerman, Salter, MacGregor, Vorhaus, 2009). Johnson (2004) states:

Cognitive development requires that the child move from reliance on others to reliance on his or her inner speech, in which the control over his or her mental functioning takes place. The beginning of the child's quest for self-regulation and cognitive independence is signaled by the emergence of egocentric speech - a vocalized form of inner speech — in which the first attempt at selfregulation emerges (p.113)

Different terms as self-directness, self-control and autonomy are used for self-regulation (Bnadura, 1991). During 1980s and 1990s, there were numbers of studies trying to shape its aspects, phases and models especially those by Bandura, Pintrich and Zimmerman (Duckworth et al., 2009). In the following years of self-regulation emergence, it becomes more goal-oriented and specific rather than a general idea in children learning and skill development. For many years, self-regulation was investigated in different fields as language disorder (LD), ADHD, impaired brain, giftness and also in academic contexts as math, writing and other disciplines (Carver \& Scheir, 1981). ). Self-regulation can be traced in pedagogy as well as educational psychology. At first, self-regulation was used to regulate learning for academic purposes (e.g. academic achievement) but these days, although with some difficulties, a number of studies focus on its concept in specific areas of second language learning as reading, writing, vocabulary and even critical thinking (Ammar, 2009; Banisaeid, 2013a; Pratontep \& Chinwonno, 2008; Ramezani, 2009; Tseng, Dorniye \& Schmitt, 2006).

\subsection{Self-regulation in educational psychology}

Since learning is defined as changes in behavior, the educational psychology deals with self-regulation from a socio cognitive perspective in which not only the person itself but also the feedback from the environment affects learning. Williams and Burden (1997) present different theories of learning, two of which are cognitive and social interaction theories. Self-regulation gets its meaning from these two theories. While cognitive theories regards learners as active meaning makers and problem solvers, social interaction theories view learning as a results of interaction between teachers, learners and tasks (Williams \& Burden, 1997). Bandura (1991) states "in social cognitive theory human behavior is extensively motivated and regulated by the ongoing exercise of self-influence" (p. 248). He presents a model of self-regulatory system through which learners are to self-monitor, judge upon their behavior and give affective self-reaction. Schunk and Zimmerman (1997) state that "as students observe their own performances, they judge them against goal standards and react to those judgments" (p.3).

From Vygodsky's (1978) point of view on children acquisition and development, until now, numbers of selfregulation models have been presented. Terry (2002) present five theories regarding self-regulation respectively: sociocognitive model, the metacognitive model, volitional control, Constructivist theory and Vygotskyian theories.

1. Socio cognitive theory of self-regulation as Zimmerman's, is broader than metacognitive skills and includes behavioral, social-behavioral sources of influence and subsequently it may affect environment and personal processes. Based on this view, self-regulation includes learner's beliefs (goal setting and self-efficacy) and self-regulated learning strategies and processes (of socio cognitive theories include self-observation, self-judgment, and self-reaction). 
2. Metacognitive model deals with cognition and affection and its main focus is on metacognition. While these two models are somehow similar, they differ in the presence of human agency

3. Volitional theories, the third model of self-regulation theories, are based on information processing model like metacognitive theory and do not involve human agency or "self".

4. Constructivist theories describe how people transform and organize reality according to common intellectual principles as a result of interactions with the environment

5. The internalization of higher psychological functions that is inner speech is the view of Vygodsky on self-regulation and is the underlying construct of self-regulation when dealing with the knowledge and self-control in the social interaction (Terry, 2002, p. 45)

The general framework of self-regulation includes four main assumptions:

1. Learners are actively participating in their own learning i.e. goals, and strategies from the information in the external and internal environment.

2. The second underlies the roles of learners in a general framework for self-regulated Learning in monitoring, controlling, and regulating their cognition, motivation and behavior and environment.

3. Third, there should be some standards or criterion to reach

4. fourth deals with the mediatory role between person and context and performance (Wolters and Pintrich and Karabenick, 2003, p.3)

By the mentioned assumptions, self-regulation is defined as:

"an active, constructive process whereby learners set goals for their learning and then attempt to monitor, regulate, and control their cognition, motivation, and behavior, guided and constrained by their goals and the contextual features in the environment and the self-regulatory activities can mediate the relations between individuals and the context and their overall achievement" (Wolters et al., 2003, p.5).

Zimmerman (1989) on the other hand defines self-regulation as" the degree that the learners are metacognitively, motivationally and behaviorally active participants in their own learning process (p. 1). In general, metacgognitively includes self-monitoring, motivationally involves affective self-reaction and behaviorally is the judgment of behavior.

\subsection{Self-regulated learning strategies}

In the self-regulation framework, there are some strategies that shape it. For checking the learners' uses of selfregulated strategies, Pintrich, Smith, Garcia, and McKeachie (1991) developed a new version of Motivated Strategies for learning questionnaire. In their model, motivation is linked to self-regulation and includes two main parts: motivation and learning strategies scales. Learning strategies scale includes cognitive and metacogintive strategies and resource management strategies. The former consists of strategies of rehearsal, elaboration, organization, critical thinking, metacognitive self-regulation and the latter includes time and study environment, effort regulation, peer learning, help seeking. Pintrich and his associates' (1991) attempt in educational psychology leading to the formation of MSLQ that today is used in some language learning research.

\subsection{Self-regulation in L2 studies}

Not only the term "self-regulation was borrowed from educational psychology, but also the questionnaires and scales measuring self-regulation is used in second language field. Banisaeid (2013b) works on 49 Chinese EFL learners' use of language learning strategy and self-regulation. She uses SILL and MSLQ respectively proposed by Oxford (1990) and Pintrich et al (1991). The finding of the study shows that there is a significant relationship between language learning strategy use and self-regulation. Nikoopour, Salimian, Salimian \& Farasani (2012) declare that "language learning strategies are one of the cognitive variables that are highly associated with success and achievement (p. 1277)”. So the learners who use more language learning strategies are more self-regulated and successful.

Tseng et al (2006) try to find a new approach for assessing strategic behavior in vocabulary learning with regards to self-regulation through three phases. At the first phase, they elaborate on five facets of self-regulation and develop the item pool by item-generating process.
1. Commitment control
2. Metacognitive control
3. Satiation control
4. Emotion control
5. Environment control (p. 87).

8 strategies under the category of metacognitive control were found. Dörnyei (2001) defines metacognition control from action control mechanisms (self-regulation) in process model of L2 motivation as "strategies for monitoring and controlling concentration and for curtailing unnecessary procrastination" (p.25). Although, Liu (2009) mentions that self-regulatory capacity vocabulary scale in Tseng et al. (2006), can serve as a diagnosis tool for self-regulatory 
capacity in English language learning, Banisaeid (2013a) found no relationship between metacognitive-based vocabulary learning and self-regulation.

\section{Discussion and Conclusion}

Dornyie (2005) declares that not only strategic framework has some problematic areas, but also self-regulatory mechanisms carry the same problems. As it was mentioned, the origin of self-regulation refers to the educational psychology in which many theories of second language learning and first language acquisition come from. But the numbers of research in the field of self-regulated language learning are rare and the reasons are:

1. There is no straightforward definition of self-regulation (Duckworth et,. al, 2009) and also it is new construct rooted in Vygotsky's (1978) work on children in regulating their own learning.

2. How this psychological concept may be added to the language learning and teaching when it is not clear that the self-regulation itself is a strategy, skill or competence.

- Since children develop the concept of self-regulation, it can be called a competence.

- Since some strategies are added to it such as metacognitive one, it can be named a strategy.

- Since according to Zimmerman (2006), all the writing processes are self-regulatory, it is also called a skill to be taught.

3. Some may conflict SR with language learning strategies because of the overlapping parts i.e. metacognitive strategies. While the former is more process oriented, the latter is more product oriented (Tsen et al. 2006). There are also some problems in defining language learning strategies themselves (Dornyei, 2005; Ellis, 1994; Tseng et al., 2006).

4. Although Pintrich and Degroot (1990), Zimmerman and Martinez-ponz (1988) and Tseng et al. (2006) use questionnaires and interviews for self-regulated learning, as stated by Pintrich (2004) "The MSLQ only measures a small portion of the potential self-regulatory strategies suggested by the model" (p. 400).

Self-regulation includes learning different strategies. Metacognitive strategies (how to set goals, evaluate, plan and monitor one's learning) as well as some affective factors such motivation and self-efficacy are part of it. So in the field of language learning, it can be a kit of strategies but not as comprehensive as the one in language learning strategies classifications by Oxford (1990) or Omally and Chamot (1989). It also includes motivational beliefs and self-efficacy that are different from motivation questioned and interviewed in Dornyie's works. Self-regulated learning is to train, improve and develop the sense of self-efficacy and motive learners in their own language learning. Any attempt to motive the learners toward their achievement (e.g. learning how to write in English) and to improve self-efficacy with setting the proper goals, giving feedback and training metacognitive strategies is related to self-regulation. Selfregulation is a broader sense while lacking specific techniques as cognitive, memory, social or compensatory ones. Although it only encompasses the metacognitive ones, the general domain of it, is meaningfully wider than the strategic framework in that it covers some aspects in the learning process as motivation, goals and self-efficacy.

\section{References}

Ammar, A. (2009). The effects of self-regulated reading strategy development on the prospective EFL teachers' critical reading skills and reading motivation. Retrieved April 2012 from http://repository.ksu.edu.sa/jspui/handle/123456789/4671.

Bandura, A. (1991). Social cognitive theory of self-regulation. Organizational Behavior and Human Decision Processes, 50, 248-287.

Banisaeid, M. (2013a). The Relationship between Self-regulated Learning Strategies and Strategy-based Vocabulary Acquisition of Iranian EFL Learners. Iranian EFL Journal, 9 (3), 80-81.

Banisaeid, M. (2013b). Self-regulation in the language study: from psychology to pedagogy. Paper presented on October 2013 in the 9th International Symposium on Teaching English at Tertiary Level, Hangzhou, China.

Brown, H, D. (2000). Principles of language learning and teaching. Pearson education.

Chamot, A. U. (1987). The learning strategies of ESL students. In A. L. Wenden \& J. Rubin (Eds.), Learner strategies in language learning (pp. 71-83). Englewood Cliffs: Prentice Hall International.

Carver, C. S. \& Scheier, M. F. (1981). Attention and self-regulation: A control theory approach human behavior. New York: Springer Verlag.

Cohen, A. D. (1998). Strategies in learning and using a second language. London: Longman.

Dörnyei , Z. (2005). The psychology of the language learner: Individual differences in second language acquisition. Mahwah, N.J.: L. Erlbaum.

Duckworth, K., Akerman, R., MacGregor, A., Salter, E. \& Vorhaus, J. (2009) Self regulation: A review of literature. Centre for the Wider Benefits of Learning. London: Institute of Education.

Goh, C. C. M. (1998). How ESL learners with different listening abilities use comprehension strategies and tactics. Language Teaching Research, 2(2), 124-147. 
Goh, C. C. M. (2002). Exploring listening comprehension tactics and their interaction patterns. System, 30(2), 185-206.

Ellis, R. (1994). The Study of Second Language Acquisition. Oxford: Oxford University Press.

Liu, HT (2009). The Scale development and causal-effect studies of self-regulation in English language learning. Unpublished Master's Thesis, National Taiwan the Normal University, Taipei, Taiwan.

Naiman, N., Fröhlich, M., Stern, H., \& Todesco, A. (1978). The good language learner. Research in Education Series No. 7. Toronto: The Ontario Institute for Studies in Education.

Nation, I. S. P. (1990). Teaching and learning vocabulary. Boston, Mass: Newbury House.

Nikoopour, J., Salimian, S., Salimian, S., \& Farasani, A. M. (2012). Motivation and the Choice of Language Learning Strategies. Journal of Language Teaching and Research,, 3 (6), 1277-1283.

O’Malley, M. J., Chamot, A.U. \& Küpper, L. (1989). Listening comprehension strategies in second language acquisition. Applied Linguistics, 10, 4, 418-437.

O'Malley, J. M., \& Chamot, A. U. (1990). Learning strategies in second language acquisition. Cambridge, England: Cambridge University Press.

Oxford, R. (1990). Language learning strategies: What every teacher should know. New York: Newbury House. Gu, Y., \& Johnson, R. K. (1996). Vocabulary learning strategies and language learning outcomes. Language Learning, 46, 643-679.

Pintrich, P. R., Smith, D. A. F., Garcia, T., \& McKeachie, W. J. (1991). A manual for the use of the Motivated Strategies for Learning Questionnaire (MSLQ). Ann Arbor: University of Michigan, National Center for Research to Improve Postsecondary Teaching and Learning.

Pratontep, Chitchon. \& Chinwonno, Apasara. (2008). Effects of Extensive Reading and Self-regulation on Thai StudentsQ English Reading Comprehension. Paper presented at the Ninth RGJ- Ph.D. Congress, Thailand, 4-7 April, 2008.

Purpura, J. (1999). Learner strategy use and performance on language tests. A structural equation modelling approach. Cambridge, England: Cambridge University Press.

Ridley, J. (1997). The role of the first language in foreign language learning. Philadelphia: Multilingual Matters.

Ramezani, A. (2009). Promoting students' attitude toward writing skills through self-regulation strategy instruction. Paper present at $7^{\text {th }}$ international TELLSI conference, Yazd, Iran.

Rose, H. (2011a). Reconceptualizing Strategic Learning in the Face of Self-Regulation: Throwing Language Learning Strategies out with the Bathwater. Journal of Applied Linguistics, 33(1), 92-98.

Rose, H. (2011b).Kanji learning: strategies, motivation control and self-regulation (Doctoral dissertation). Retrieved from http://www.academia.edu/446999/Kanji_learning_Strategies_Motivation_control_and_self-regulation

Rubin, J. (1975). What the "good language learner" can teach us. TESOL Quarterly, 9, 41-51

Schmeck, R. R. (1988). Individual differences and learning strategies. In C. E Weinstein, E. T. Goetz \& P. A. Alexander (Eds.), Learning and study strategies: Issues in assessment, Instruction, and Evaluation 171-191. San Diego: Academic Press.

Schunk, D. H. \& Zimmerman B. J. (1997). Developing self-efficacious readers and writers: The role of social and selfregulatory processes. In Reading engagement: Motivating readers through integrated instruction, 34-50., ed. J. T. Guthrie and A. Wigfield. Newark, DE: International Reading Association.

Stern, H. H. (1975). What can we learn from the good language learner? Canadian Modern Language Review, 34, 304-318.

Stern, H. H. (1986). Fundamental concepts of language teaching. Oxford: Oxford University Press.

Stern, H. H. (1992). Issues and options in language teaching. London: Oxford University Press.

Terry, P. (2002). The effects of online time management practices on self regulated learning and academic selfEfficacy. Dissertation of curriculum \& instruction, Virginia University.

Tseng, W. T., Dörnyei, Z. \& Schmitt, N. (2006). A new approach to assessing strategic learning: the case of selfregulation in vocabulary acquisition. Applied Linguistics,78-102.

Tarone, E. (1981). Some thoughts on the notion of communication strategy. TESOL Quarterly, 15(3), 285-295.

Weinstein, C. E., \& Mayer, R. E. (1986). The teaching of learning strategies. In M. C. Wittrock (Ed.), Handbook of research on teaching (pp. 315-327). New York: Macmillan.

Wenden, A. L. (1987). Incorporating learner training in the classroom. In A. L. Wenden \& J. Rubin (Eds.), Learner strategies in language learning (pp. 159-168). Englewood Cliffs, NJ: Prentice Hall.

Williams, M. \& R. Burdon. 1997. Psychology for language teachers. Cambridge: Cambridge University Press.

Wolters, C., Pintrich, P. R. \& Karabenick, S. A. (2003). Assessing academic self-regulated learning. Paper presented at the Indicators of Positive Development Conference, Washington, DC, March 12-13, 1-49.

Zimmerman, B. J. (1989). A social cognitive view of self-regulated academic learning. Journal of Educational Psychology, 81, 329-339. 